\title{
Endostatin and anastellin inhibit distinct aspects of the angiogenic
} process

\author{
David M Neskey, Anthony Ambesi, Kevin M Pumiglia and Paula J McKeown- \\ Longo*
}

Address: Center for Cell Biology \& Cancer Research, Albany Medical College, Albany, New York 12208, USA

Email: David M Neskey - neskyd@mail.amc.edu; Anthony Ambesi - ambesia@mail.amc.edu; Kevin M Pumiglia - pumiglk@mail.amc.edu; Paula J McKeown-Longo* - mckeowp@mail.amc.edu

* Corresponding author

Published: 4 November 2008

Journal of Experimental \& Clinical Cancer Research 2008, 27:6I doi:I0.1 I86/1756-9966-27-6I

This article is available from: http://www.jeccr.com/content/27/I/6I

(C) 2008 Neskey et al; licensee BioMed Central Ltd.

This is an Open Access article distributed under the terms of the Creative Commons Attribution License (http://creativecommons.org/licenses/by/2.0), which permits unrestricted use, distribution, and reproduction in any medium, provided the original work is properly cited.

\begin{abstract}
Background: Endostatin and anastellin, fragments of collagen type XVIII and fibronectin, respectively, belong to a family of endogenous inhibitors of angiogenesis which inhibit tumor growth and metastasis in a number of mouse models of human cancer. The mechanism of action of these inhibitors is not well understood, but they have great potential usefulness as non-toxic long-term therapy for cancer treatment.
\end{abstract}

Methods: In this study, we compare the anti-angiogenic properties of endostatin and anastellin using cell proliferation and transwell migration assays.

Results: Anastellin but not endostatin completely inhibited human dermal microvessel endothelial cell proliferation in response to serum stimulation. Both anastellin and endostatin additively inhibited endothelial cell migration in response to VEGF. Anastellin but not endostatin lowered basal levels of active ERK.

Conclusion: These data indicate that anastellin and endostatin exert their anti-angiogenic effects by modulating distinct steps in the angiogenic pathway and suggest that matrix-derived inhibitors of angiogenesis may exhibit higher efficacy when used in combination.

\section{Background}

Angiogenesis, the development of new blood vessels from pre-existing vessels, has been pushed toward the front of cancer research because of its potential therapeutic applications. The angiogenic potential of endothelial cells is determined by a complex balance of positive and negative regulators of growth, migration, invasion and tubulogenesis. Among these regulators are growth factors, such as VEGF, integrin adhesion receptors and extracellular matrix molecules $[1,2]$. Peptides derived from the extracellular matrix of the tumor microenvironment have been reported to regulate tumor progression and angiogenesis in a variety of mouse models of human cancer and have the potential for developing into promising anti-neoplastic therapies targeting the angiogenic process [3]. Endostatin, a $20 \mathrm{kD}$ terminal fragment of collagen XVIII, is believed to be generated locally in the tumor environment through the action of proteases [4]. Endostatin has exhibited anti-angiogenic properties and anti-tumor activity in a wide variety of human and murine primary and metastatic tumors growing in mice (reviewed in [5]). Although the exact mechanism is unknown, endostatin has been 
shown to inhibit proliferation and induce apoptosis in some endothelial cell lines [6-9]. Microarray studies have shown that endostatin can regulate up to $12 \%$ of all human genes in microvessel cells. Many of these genes are known regulators of angiogenesis [10]. These studies indicate that the effects of anastellin are not linked to one particular signaling pathway, but rather that endostatin impacts a broad network of potentially intersecting pathways important in the angiogenic phenotype. Several receptors have been implicated in mediating the effects of endostatin. These include $\alpha 5 \beta 1$ integrins, selectins or cell surface heparan sulfate proteoglycans [11-15].

Anastellin, a $10 \mathrm{kD}$ fragment derived from the first type III repeat of fibronectin $\left(\mathrm{III}_{1 \mathrm{c}}\right)$, is another anti-angiogenic peptide that inhibits tumor growth and metastasis in vivo [16]. The anti-tumor activity of anastellin has been proposed to result from inhibitory effects on angiogenesis as tumors in anastellin-treated mice exhibit reduced blood vessel density [17]. In vitro, studies using human microvessel endothelial cells show that anastellin inhibits serum dependent cell growth by blocking progression of the cell cycle [18]. The mechanism of action of anastellin is not well understood. It has been reported to bind to $\alpha 5 \beta 1$ integrins and proteoglycans [19] and shown to affect the activity of several intracellular signaling molecules [18-21]. Anastellin also binds fibronectin and promotes changes in the organization and assembly of the fibronectin matrix $[20,21]$.

To date, there are no studies which directly compare the effects of these inhibitors on endothelial cell function. We have used human microvessel endothelial cells to compare the effects of anastellin and endostatin on serumdependent growth and VEGF-dependent cell migration. We find that endostatin and anastellin exhibit distinct effects on microvessel cell proliferation and migration which are likely mediated through differing effects on MAP-Kinase pathways.

\section{Methods \\ Reagents}

Unless otherwise indicated, chemical reagents were obtained from Sigma Chemical Co. (St Louis, MO). Recombinant anastellin ( $\mathrm{III}_{1 \mathrm{C}}$ ) was expressed and purified as previously described [21]. Recombinant human endostatin prepared in yeast (Pichia pastoris) was from Molecular Probes (Eugene, OR). Yeast preparations of recombinant human endostatin have been shown to inhibit in vitro angiogenesis and tumor growth [22-24]. Monoclonal antibodies to phospho-ERK (E10) and rabbit polyclonal antibodies to p38 and phospho-p38 (Thr-180/ Tyr-182) were obtained from Cell Signaling Tech (Beverly, MA). Rabbit polyclonal antibodies to ERK2 were obtained from Santa Cruz Biotechnology, Inc. (Santa Cruz, CA).
Anti-CD146 monoclonal antibody (clone P1H12) was obtained from Chemicon International Inc. (Temecula, CA). Vitrogen-100 was from Cohesion Technologies (Palo Alto, CA).

\section{Cell culture}

Primary adult human dermal microvessel endothelial cells were obtained from VEC Technologies Inc (Rensselaer, NY). Cells were maintained in complete medium [MCDB-131 supplemented with $20 \%$ defined fetal bovine serum (D-FBS; HyClone Labs, Logan, UT), $2 \mathrm{mM}$ Glutamax (Gibco), EGM-2MV SingleQuots growth factor cocktail (Cambrex Corp, East Rutherford, NJ), and $10 \mu \mathrm{g} /$ $\mathrm{ml}$ heparin] and cultured on collagen-coated $(20 \mu \mathrm{g} / \mathrm{ml}$ Vitrogen-100) tissue culture dishes.

\section{Cell proliferation assay}

Endothelial cells were seeded (500 cells/well) in complete medium (without heparin) onto collagen-coated 24-well plates and allowed to settle for 4 hours. Endostatin and anastellin were added to seeded cells and cells were grown at $37^{\circ} \mathrm{C}$ in $5 \% \mathrm{CO}_{2}$ for up to 6 days. At time points, plates were fixed in 3\% paraformaldehyde and stored in PBS at $4{ }^{\circ} \mathrm{C}$. Endothelial cells were quantified indirectly by ELISA using a mouse anti-endothelial cells (CD146) monoclonal antibody (clone P1H12) as previously described [18].

\section{Transwell migration assay}

Transwell polycarbonate plates with $6.5 \mathrm{~mm}$ diameter tissue culture inserts containing a membrane with $8 \mu \mathrm{m}$ pores were coated with $20 \mu \mathrm{g} / \mathrm{ml}$ of Vitrogen-100 overnight at $37^{\circ} \mathrm{C}$ in an atmosphere of $5 \% \mathrm{CO}_{2}$. Following incubation, inserts were washed once with PBS and blocked with $1 \% \mathrm{BSA} / \mathrm{PBS}$ for 1 hour at $37^{\circ} \mathrm{C}$. washed and allowed to dry. Cells were suspended in serum free MCDB-131 and seeded $\left(5 \times 10^{4}\right.$ cells/well $)$ into each insert in the presence of endostatin and/or anastellin. In each outer well, $600 \mu \mathrm{l}$ of medium with a peptide concentration matching its inner well was added. The plates are then assembled and incubated for 1 hour at $37^{\circ} \mathrm{C}$ and 10 $\mathrm{ng} / \mathrm{ml}$ of vascular endothelial growth factor (VEGF) was added to each of the outer wells. After a 4-hour incubation, the plates were rinsed once in PBS, fixed in 3\% formaldehyde/PBS for 15 minutes, and rinsed with $0.5 \%$ crystal violet. Cells adhering to the top surface of the tissue culture inserts were removed with a cotton tip applicator while cells adhering to the bottom surface of the inserts were rinsed and permeability with $1 \%$ Triton-X 100 in PBS for 20 minutes. Subsequently, cells were stained with Hoechst $33258(1 \mu \mathrm{g} / \mathrm{ml}$ in PBS) for 30 minutes in the dark and then viewed under the fluorescent microscope and the number of cells in 3 random 10x magnification fields was determined. 


\section{Results \\ Effects of anastellin and endostatin on endothelial cell proliferation}

Experiments were designed to compare the effect of anastellin and endostatin on microvessel endothelial cell growth. Endothelial cells were seeded in complete medium (20\% serum and growth factor cocktail) into collagen-coated wells. Figure 1 shows that the addition of anastellin inhibited serum/growth factor dependent growth in a dose-dependent manner. The inhibitory effects of anastellin on growth were quantified 3 days after seeding (day 4) and again at 5 days after seeding (day 6) (Figure 1). In contrast, endostatin treatment had no effect on microvessel cells which continued to grow at the same rate as control cells. Anastellin treatment did not result in a loss of cells due to disruption of adhesion as cells initially seeded remained attached and spread during the entire 5-day assay (data not shown). These data indicate that in the presence of a complex medium of growth factors, anastellin but not endostatin is a very effective inhibitor of endothelial microvessel cell growth.

\section{Effect of anastellin and endostatin on endothelial cell migration}

To evaluate the effects anastellin and endostatin on endothelial cell motility, microvessel cells were seeded onto collagen-coated filters in modified Boyden chambers. As shown in Figure 2, the addition of VEGF to the bottom chamber as a chemoattractant resulted in a twofold increase in the number of cells migrating to the bottom of the filter. Addition of anastellin caused a dosedependent decrease in VEGF-stimulated cell migration. Complete inhibition of VEGF-stimulated migration was seen at $10 \mu \mathrm{M}$ anastellin. Endostatin also inhibited VEGFinduced migration, but the effects were only partial. Endostatin inhibited VEGF-induced migration by 40$50 \%$ over the dose range tested. This result is consistent with previous studies where endostatin was shown to inhibit VEGF stimulated migration by $60-70 \%[25,26]$.

Experiments were done to address whether the effects of anastellin and endostatin on cell migration were additive. Based on the results shown in Figure 2, doses of each peptide were selected which would give partial inhibition of migration. As shown in Figure 3, $0.04 \mu \mathrm{M}$ endostatin inhibited migration by approximately 35\%, $2.5 \mu \mathrm{M}$ anastellin inhibited migration by approximately $60 \%$. When added together, there was greater than a $95 \%$ inhibition of migration. These data indicate that the effect of these inhibitors on migration are additive and suggest that they exert independent effects on cell migration.

\section{Effect of endostatin and/or anastellin on basal levels of MAP kinase activity}

As ERK and p38 MAP kinase have been reported to regulate growth and migration of endothelial cells in response to growth factors including VEGF [27-29], we compared anastellin and endostatin for their effects on the basal activities of these MAP kinases in microvessel cells. Cells were incubated with either anastellin or endostatin for 1 hour. The doses used were those shown to inhibit either proliferation (Figure 1) or migration (Figure 2). Following treatment, cell lysates were analyzed for active ERK (pERK) or p38 MAP kinase (p-p38) by Western blot. Figure $4 \mathrm{~A}$ shows that increasing doses of anastellin caused a marked increase in the activation of p38 and a nearly complete loss of active ERK. The effects of anastellin on the MAP kinase activities were dose-dependent between 5-20 $\mu \mathrm{M}$ and correlated well with the amounts of anastellin required to inhibit cell proliferation and migration (Figures 1 and 2). In contrast, endostatin had no effect on the levels of active p38 or ERK when used at doses shown to cause an inhibition of migration (Figure 2). Figure $4 \mathrm{~B}$ shows that the effects of anastellin on MAP kinase activity occurred within minutes. Maximal activation of p38 was seen between 30-40 minutes, while inhibition of ERK was seen by 10 minutes. Consistent with the results shown in Figure 4A, endostatin and anastellin exert differential effects on the activity of ERK and p38 MAP kinases and suggest that these peptides inhibit angiogenesis by modulating distinct signaling pathways in microvessels cells.

\section{Discussion}

The present study shows that anastellin, but not endostatin, is an effective inhibitor of microvessel cell growth in response to growth factor supplemented serum. These findings differ from earlier studies showing that endostatin could inhibit bFGF- or VEGF-stimulated endothelial cell growth $[6,28,30-33]$ or in vivo angiogenesis in response to VEGF [34]. The discrepancy between these earlier results and the current data may be due to differences in the assay system (serum-dependent growth) or in the cell type (human microvessel endothelial cells). In agreement with this, other studies have shown that the effects of endostatin on endothelial cells can be quite varied depending on the endothelial cell source [35]. Although microarray studies have shown that endostatin targets a large number of genes [36], our studies suggest that anastellin effects a broader base of targets to include those important in proliferation of endothelial cells. Taken together, these data suggest that endostatin may selectively inhibit signaling through individual growth factor receptors but it may be less effective in inhibiting growth in response to a more complex mixture of growth stimulatory signals. Anastellin and endostatin have both been reported to bind to $\alpha 5 \beta 1$ and heparan sulfate proteoglycans $[12,19,37]$. This would suggest that these two 

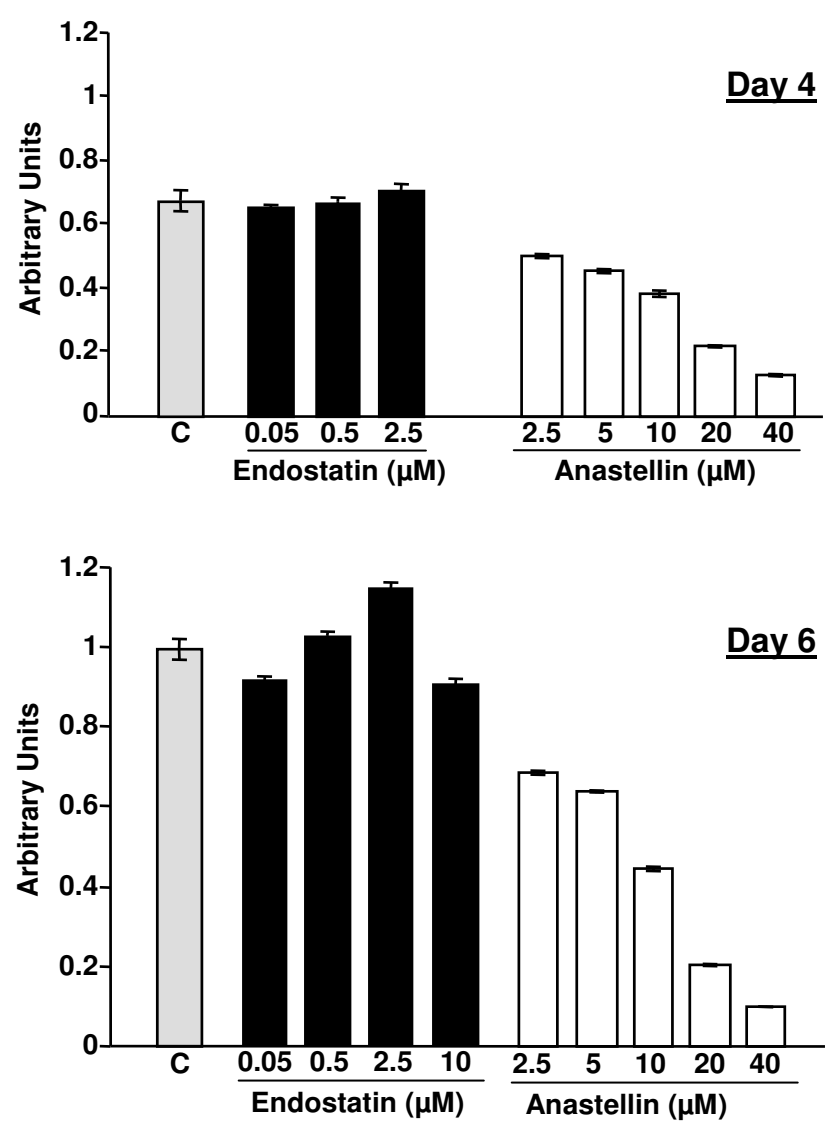

Figure I

Effects of anastellin and endostatin on endothelial cell proliferation. Microvessel cells were seeded (500 cells/ well) in the presence of complete medium (day I). After 4 hours, anastellin or endostatin was added to the medium. At day 4 and ay 6 , the number of cells was determined by ELISA. Control wells $(C)$ received no peptide. All wells were normalized to the 6-day control which was set at I. Error bars represent standard error of the mean of triplicate samples.

peptides might exert similar effects on cell behavior. However, in this study we have found that these two peptides exhibit distinct effects on both cell behavior and MAP kinase pathways. Consistent with this observation, we have found more recently that the effects of anastellin on p38 are independent of $\beta 1$ integrins [38].

The effects of anastellin and endostatin on cell migration indicate that combined regimens of matrix-derived peptides and provide additive levels of inhibition. Other angiogenesis inhibitors derived from matrix molecules regulate effects on endothelial cells through a variety of mechanisms. Tumstatin, a fragment of Type IV collagen, inhibits endothelial cell proliferation and induces apoptosis through the mTOR pathway but has no effect on cell migration [39]. Canstatin, another fragment of the Type
IV collagen, has also been shown to inhibit serumdependent cell proliferation and induce apoptosis. Unlike anastellin, canstatin's inhibition of cell proliferation was not associated with changes in ERK activity but were dependent upon apoptotic signaling events transduced through membrane death receptors $[40,41]$. In contrast to other Type IV collagen fragments, arrestin which is derived from the $\alpha 1$ chain of type IV collagen does not induce apoptosis but inhibits endothelial cell proliferation and migration and their associated signaling pathways including ERK1/2, FAK, and p38 MAPK [42]. As each of these matrix-derived peptides activate distinct anti-angiogenic pathways, it is probable that combinations of matrix-derived peptides would result in synergistic inhibition of not only cell migration but also of neovascularization in general $[43,44]$. In addition, these peptides may augment the anti-tumor effects of more traditional chemotherapeutic agents or oncolytic viruses [45-49].

The basis for endostatin's or anastellin's inhibitory effects on tumor growth and metastasis in vivo may extend beyond direct effects on the tumor vasculature to more widespread effects on the tumor microenvironment. Endostatin has been shown to exhibit direct effects on tumors. Endostatin treated mice undergoing carcinogeninduced skin tumors exhibit less aggressive more differentiated tumors, suggesting that endostatin regulates terminal differentiation of keratinocytes [50]. When given in combination with angiostatin during the early states of prostate cancer in the TRAMP mouse, endostatin arrested the progression of moderately differentiated carcinoma to poorly differentiated carcinoma [51]. Anastellin has also been shown to activate signaling pathways in dermal fibroblasts, suggesting that anastellin may elicit biologic effects on stromal cells present within the tumor $[20,21]$. The extravascular effects of matrix-derived inhibitors of angiogenesis within the tumor microenvironment represent an important area of future investigation.

\section{Conclusion}

Our data indicate that the matrix-derived inhibitors of angiogenesis, endostatin and anastellin, exhibit effects on endothelial microvessel cell proliferation and migration which are associated with differing effects of MAP kinase activity. These findings suggest that combinatorial antiangiogenic therapies may provide novel treatments for the management of cancer as a chronic disease.

\section{Competing interests}

The authors declare that they have no competing interests.

\section{Authors' contributions}

DMN and AA performed experiments and provided statistical analysis. KMP provided technical assistance, experimental design and data interpretation. PJM-L provided 


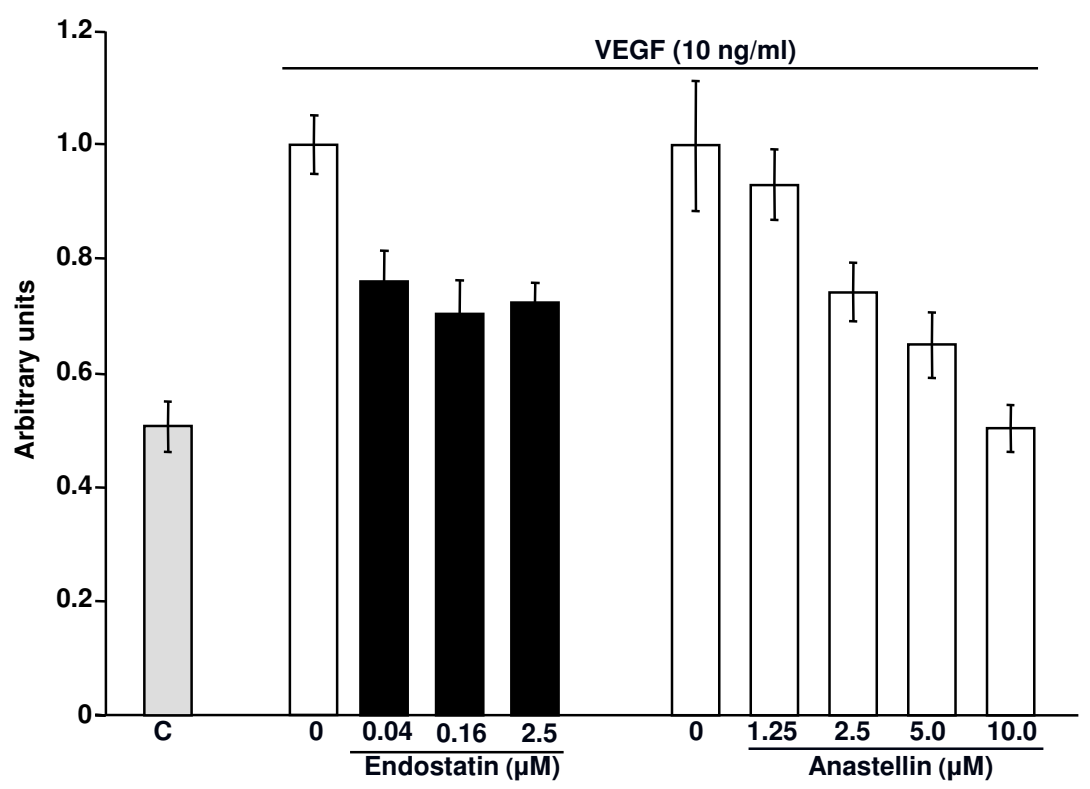

Figure 2

Effects of anastellin and endostatin on VEGF-dependent endothelial cell migration. Endothelial cells were seeded on collagen-coated transwell tissue culture inserts in the presence of either anastellin or endostatin, which was added to both upper and lower chambers. Control wells $(\mathrm{C}$ or 0$)$ received no peptide. Positive control wells $(0)$ were set at $\mathrm{I}$ and represent VEGF migration. After I hour, the $10 \mathrm{ng} / \mathrm{ml}$ VEGF was added to the lower chamber as chemoattractant. After 4 hours, the plates were fixed, stained and cells in three $10 \times$ fields counted in each of 3 membranes. The bars represent standard error of the mean from 3 separate experiments $(n=27)$.

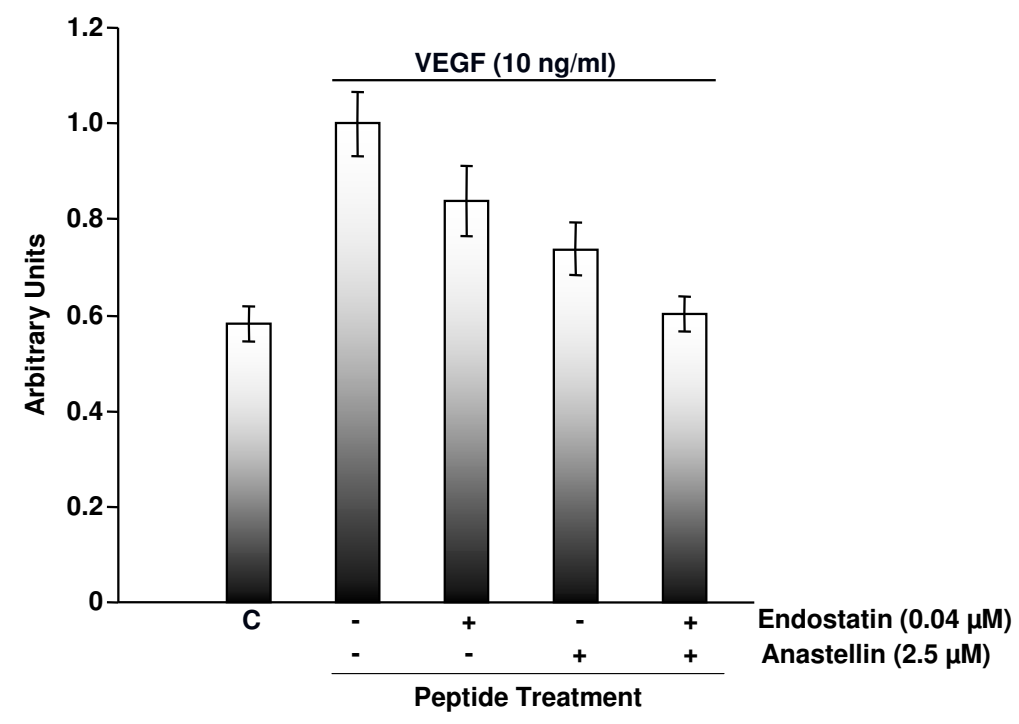

\section{Figure 3}

The effects of anastellin and endostatin on endothelial cell migration are additive. Endothelial cells were seeded on collagen-coated transwells in the presence of endostatin or anastellin either individually or in combination. Peptides were added to both chambers at the time of seeding. After I hour, $10 \mathrm{ng} / \mathrm{ml}$ VEGF was added to the lower chamber. Control wells (C) received no peptides and no VEGF and represent baseline migration. Positive control wells $(+)$ were set at I and represent VEGF dependent migration. After 4 hours, plates were fixed, stained and the number of cells migrating to the underside of the filter were counted in three $10 \times$ fields in each of triplicate wells. Bars represent standard error of the mean from data obtained from 7 separate experiments, $n=63$. 
A

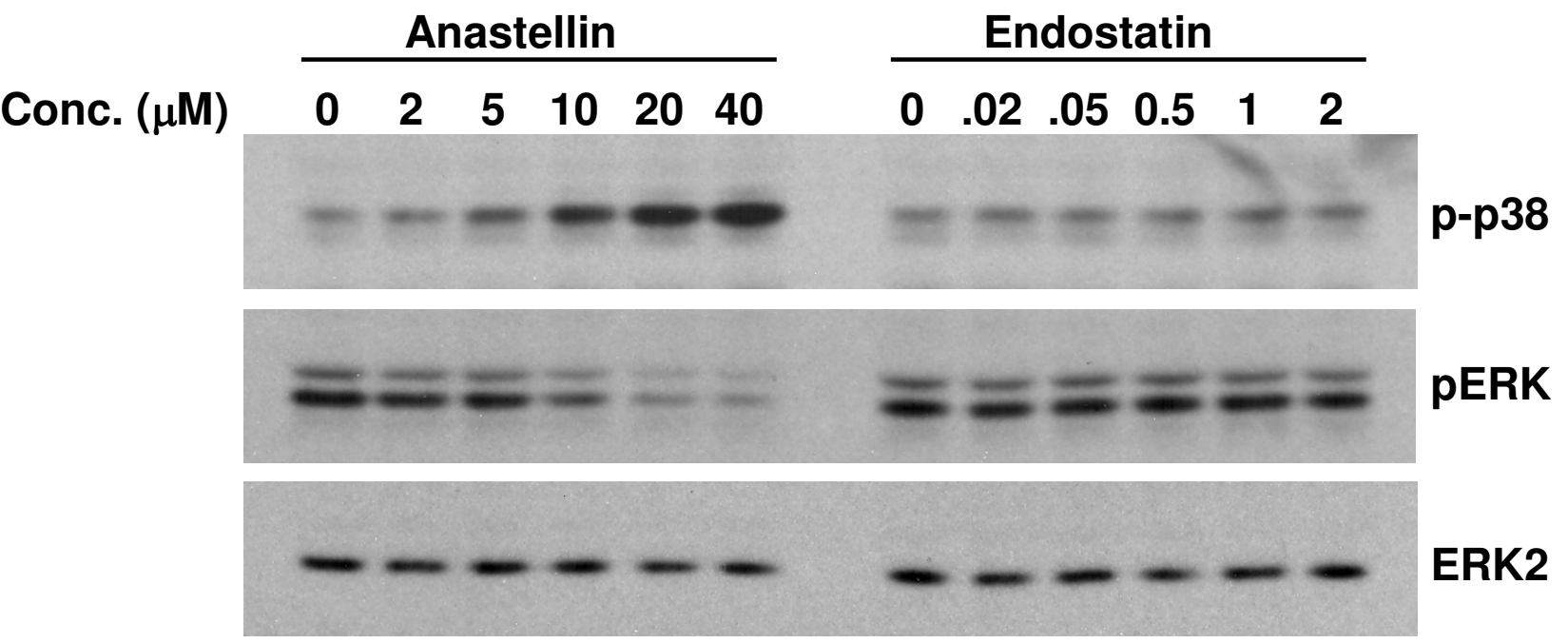

B

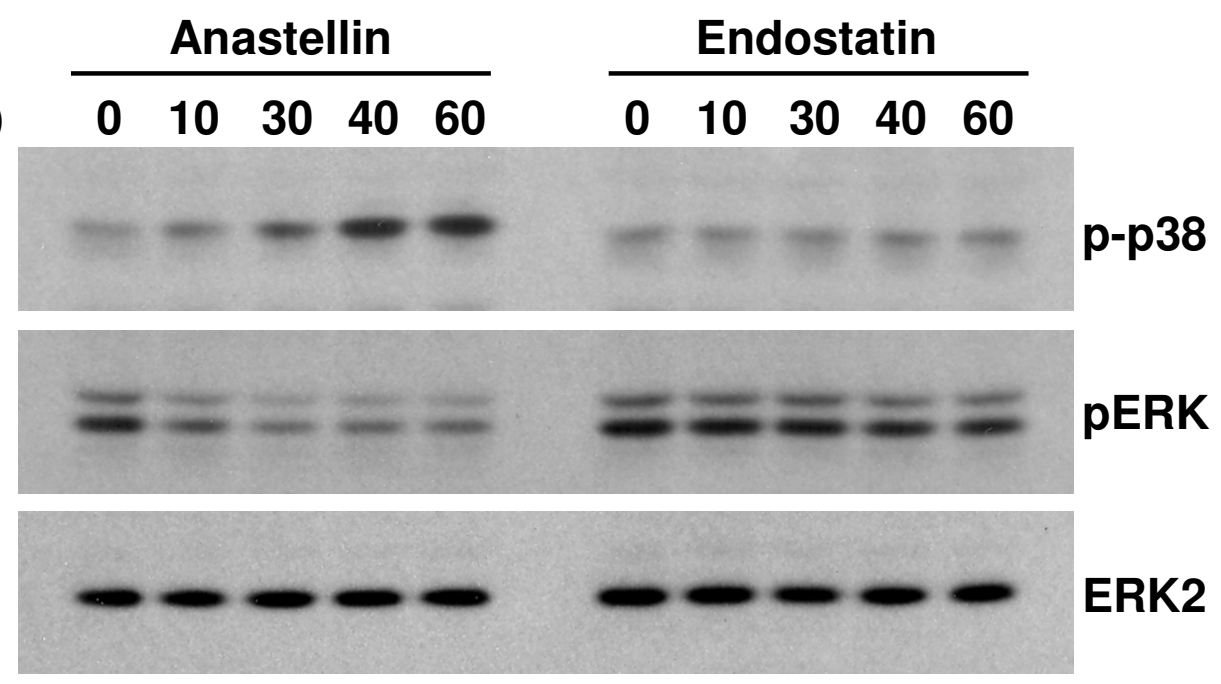

Figure 4

Effect of anastellin and endostatin on ERK and p38 MAP kinase activity. Micro-vessel cell monolayers were treated with the indicated doses of either anastellin or endostatin for I hour (A) or treated with $20 \mu M$ anastellin or $0.5 \mu M$ endostatin for the indicated time (B). Cell layers were washed twice with ice-cold PBS containing I $\mathrm{mM} \mathrm{Na}_{3} \mathrm{VO}_{4}$, solubilized in gel sample buffer. Cell lysates were prepared and analyzed by Western blot for phospho-ERK and phospho-p38 MAP kinase. Blots were then stripped and reprobed for either total ERK as a loading control. Additional controls indicated no change in the levels of p38 (data not shown).

conceptual oversight on the project including manuscript design and interpretation of experiments as well as responsibility for final draft of the manuscript.

\section{Acknowledgements}

Supported by NIH CA696I2 (PM-L) and NIH CA08I4I9 (KMP).
References

I. Kerbel RS: Tumor angiogenesis. New Eng J Med 2008, 358:2039-2049.

2. Nyberg P, Salo T, Kalluri R: Tumor microenvironment and angiogenesis. Frontiers in Biosci 2008, 13:6537-6553.

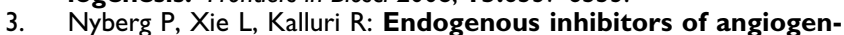
esis. Cancer Res 2008, 65:3967-3979.

4. Felbor U, Dreier L, Bryant RA, Ploegh HL, Olsen BR, Timple R: Secreted cathespin $L$ generates endostatin from collagen XVIII. EMBO J 2000, 19:1 187-I194. 
5. Folkman J: Antiangiogenesis in cancer therapy-endostatin and its mechainsms of action. Exp Cell Res 2006, 3 I 2:594-607.

6. O'Reilly MS, Boehm T, Shing Y, Fukai N, Vasios G, Lane WS, et al: Endostatin: an endogenous inhibitor of angiogenesis and tumor growth. Cell 1997, 88:277-285.

7. Hanai J, Dhanabal M, Karumanchi SA, Albanese C, Waterman M, Chan $B$, et al.: Endostatin causes $\mathbf{G I}$ arrest of endothelial cells through inhibition of cyclin DI. J Biol Chem 2002, 277(19): 16464-16469.

8. Salvesen GS, Dixit VM: Caspases: Intracellular signaling by proteolysis. Cell 1997, 91:443-446.

9. lozzo RV: The biology of the small leucine-rich proteoglycans. J Biol Chem 1999, 274:18843-18846.

10. Abdollahi A, Hahnfeldt P, Maercker C, Grone HJ, Debus J, Ansorge $\mathrm{W}$, et al.: Endostatin's antiangiogenic signaling network. Mol Cell 2004, I 3:649-663.

II. Rehn M, Veikkola T, Kukk-Valdre E, Nakamura H, Ilmonen M, Lombardo $C$, et al.: Interaction of endostatin with integrins implicated in angiogenesis. Proc Natl Acad Sci USA 200 I, 98: I 024- 1029.

12. Sudhakar A, Sugiomoto H, Yang C, Lively J, Zeisberg M, Kalluri R Human tumstatin and human endostatin exhibit distinct antiangiogenic activities mediated by $\alpha v \beta 3$ and $\alpha 5 \beta$ I integrins. Proc Natl Acad Sci USA 2003, 100:4766-477I.

13. Yu Y, Moulton KS, Kahn MK, Vineberg S, Boye E, Davis VM, et al.: Eselectin is required for the antiangiogenic activity of endostatin. Proc Natl Acad Sci USA 2004, 101:8005-8010.

14. Karumanchi SA, Jha V, Ramchandran R, Karihaloo A, Tsiokas L, Chan $B$, et al:: Cell surface glypicans are low-affinity endostatin receptors. Mol Cell 200I, 7:8II-822.

15. Wickstrom SA, Alitalo K, Keski-Oja J: Endostatin associates with lipid rafts and induces reorganization of the actin cytoskeleton via down-regulation of RhoA activity. J Biol Chem 2003, 278:37895-3790।

16. Pasqualini R, Bourdoulous S, Looivunen E, Woods VL Jr, Ruoslahti E: A polymeric form of fibronectin has antimetastatic effects against multiple tumor types. Nat Med 1996, 2: I I97-I 203.

17. Yi M, Ruoslahti $E:$ A fibronectin fragment inhibits tumor growth, angiogenesis, and metastasis. Proc Natl Acad Sci 200I, 98:620-624.

18. Ambesi A, Klein RM, Pumiglia KM, McKeown-Longo PJ: Anastellin, a fragment of the first type III repeat of fibronectin, inhibits extracellular signal-regulated kinase and causes $\mathbf{G I}$ arrest in human microvessel endothelial cells. Cancer Res 2005 , 65:148-156.

19. Mercurius $K$, Morla A: Cell adhesion and signaling on the fibronectin Ist type III repeat; requisite roles for cell surface proteoglycans and integrins. BMC Cell Biol 200I, 2:18-30.

20. Bourdoulous S, Orend G, MacKenna DA, Pasqualini R, Ruoslahti E: Fibronectin matrix regulates activation of RHO and CDC42 GTPases and cell cycle progression. J Cell Biol 1998, I 43:267-276.

21. Klein RM, Zheng M, Ambesi A, Water L van de, McKeown-Longo PJ: Stimulation of extracellular matrix remodeling by the first type III repeat in fibronectin. J Cell Sci 2003, I I6:4663-4674.

22. Sorensen DR, Read TA, Porwol T, Olsen BR, Timpl R, Sasaki T, et al.: Endostatin reduces vascularization, blood flow, and growth in rat gliosarcoma. Neuro Oncol 2002, 4:I-8.

23. Skovseth DK, Veuger MJ, Sorensen DR, De Angelis PM, Haraldsen G: Endostatin dramatically inhibits endothelial cell migration, vascular morphogenesis, and perivascular cell recruitment in vivo. Blood 2005, 105: 1044-1051.

24. Marneros AG, She H, Zambarakji H, Hashizume H, Connolly EJ, Kim I, et al.: Endogenous endostatin inhibits choroidal neovascularization. FASEB 」 2007, 21:3809-38/8.

25. Eriksson K, Magnusson P, Dixelius J, Claesson-Welch L, Cross M: Angiostatin and endostatin inhibit endothelial cell migration in response to FGF and VEGF without interfering with specific intracellular signal transduction pathways. FEBS Letters 2003, 536:19-24.

26. Ergun S, Kilic N, Wurmbach JH, Ebrahimnejad A, Fernando M, Sevinc $S$, et al.: Endostatin inhibits angiogenesis by stabilization of newly formed endothelial tubes. Angiogenesis 200I, 4:193-206.

27. Boehm T, Folkman J, Browder T, O'Reilly MS: Antiangiogenic therapy of experimental cancer does not induce acquired drug resistance. Nature 1997, 390:404-407.
28. Kim Y-M, Hwang S, Kim Y-M, Pyun B-J, Kim T-Y, Lee S-T, et al:: Endostatin blocks vascular endothelial growth factor-mediated signaling via direct interaction with KDR/Flk-I. J Biol Chem 2002, 277:27872-27879.

29. Issbrucker K, Marti HH, Hippenstiel S, Vowinckel R, Gaumann A, Breier G, et al.: p38 MAP kinase - a molecular switch between VEGF-induced angiogenesis and vascular hyperpermeability. FASEB J 2003, 17:262-264.

30. O'Reilly MS, Holmgren L, Shing Y, Chen C, Rosenthal RA, Moses M, et al.: Angiostatin: a novel angiogenesis inhibitor that mediates the suppression of metastases by a Lewis lung carcinoma. Cell 1994, 79:315-328.

31. Hanai J, Dhanabal M, Karumanchi SA, Albanese C, Waterman M, Chang B, et al.: Endostatin causes $\mathbf{G}_{\boldsymbol{b}}$ arrest of endothelial cells through inhibition of cyclin DI. I Biol Chem 2002, 277: 16564-16469.

32. Heljasvaara R, Nyberg P, Luostarinen J, Parikka M, Heikkila P, Rehn M, et al.: Generation of biologically active endostatin fragments from human collagen XVIII by distinct matrix metalloproteases. Exp Cell Res 2005, 307:292-304.

33. Reis RC, Schuppan D, Barreto AC, Bauer M, Bork JP, Hassler G, et al.: Endostatin competes with bFGF for binding to heparin-like glycosaminoglycans. Biochem Biophys Res Commun 2005, 333:976-983

34. Zhang X, Hu J, Lawler J, Terwillliger E, Parangi S: Adeno-associated virus-mediated antiangiogenic gene therapy with thrombospondin-I type I repeats and endostatin. Clin Cancer Res 2007, 13:3968-3976.

35. Schmidt A, Addicks K, Bloch W: Opposite effects of endostatin on different endothelial cells. Cancer Biol Ther 2004, 3: I I62-I I 66.

36. Abdollahi A, Lipson KE, Sckell A, Zieher H, Klenke F, Poerschke D, et al.: Combined therapy with direct and indirect angiogenesis inhibition results in enhanced antiangiogenic and antitumor effects. Cancer Res 2003, 63:8890-8898.

37. Wickstrom SA, Alitalo K, Keski-Oja J: An endostatin-derived peptide interacts with integrins and regulates actin cytoskeleton and migration of endothelial cells. I Biol Chem 2004, 279:20178-20185.

38. You R, Klein RM, Zheng M, McKeown-Longo PJ: Regulation of p38 MAP kinase by anastellin is independent of anastellin's effect on matrix fibronectin. Matrix Biol 2008 in press.

39. Maeshima Y, Sudhakar A, Lively JC, Ueki K, Kharbanda S, Kahn CR, et al: Tumstatin, an endothelial cell-specific inhibitor of protein synthesis. Science 2002, 295: I 40-143.

40. Panka DJ, Mier JW: Canstatin inhibits Akt activation and induces Fas-dependent apoptosis in endothelial cells. J Biol Chem 2003, 278:37632-37636.

4I. Kamphaus GD, Colorado PC, Panka DJ, Hopfer H, Ramchandran R, Torre A, et al.: Canstatin, a novel matrix-derived inhibitor of angiogenesis and tumor growth. J Biol Chem 2000, 275: $1209-1215$

42. Sudhakar A, Nyberg P, Keshamouni VG, Mannam AP, Li J, Sugimoto $\mathrm{H}$, et al: Human $\alpha \mathbf{I}$ type IV collagen NCI domain exhibits distinct antiangiogenic activity mediated by $\alpha|\beta|$ integrin. J Clin Invest 2005, I 1 5:280I-28I0.

43. Ohlfest JR, Demorest ZL, Motooka Y, Vengco I, Oh S, Chen E, et al. Combinatorial antiangiogenic gene therapy by nonviral gene transfer using the sleeping beauty transposon causes tumor regression and improves survival in mice bearing intracranial human glioblastoma. Mol Ther 2005, I 2:778-788.

44. McKeown-Longo PJ, Mosher DF: Mechanism of formation of disulfide-bonded multimers of plasma fibronectin in cell layers of cultured human fibroblasts. I Biol Chem 1984, 259:12210-12215.

45. Zhang Q, Nie M, Sham J, Su C, Xue H, Chua D, et al.: Effective geneviral therapy for telomerase-positive cancers by selective replicative-competent adenovirus combining with endostatin gene. Cancer Res 2004, 64:5390-5397.

46. Isayeva T, Ren C, Ponnazhagan S: Intraperitoneal gene therapy by rAAV provides long-term survival epithelial ovarian cancer independently of survivin pathway. Gene Ther 2007, 14:138-146.

47. Li X, Liu YH, Lee SJ, Gardner TA, Jeng MH, Kao C: Prostaterestricted replicative adenovirus expressing human endostatin-angiostatin fusion gene exhibiting dramatic antitumor efficacy. Clin Cancer Res 2008, I4:29I-299. 
48. Li J, Dong $X, X u Z$, Jiang $X$, Jiang H, Krissansen GW, et al.: Endostatin gene therapy enhances the efficacy of paclitaxel to suppress breast cancers and metastases in mice. J Biomed Sci 2008, 15:99-109.

49. Yao B, He QM, Tian L, Xiao F, Jiang Y, Xhang R, et al:: Enhanced antitumor effect of the combination of tumstatin gene therapy and gemcitabine in murine models. Human Gene Therapy 2005, 9:1075-1086.

50. Brideau G, Makinen J], Elamaa H, Tu H, Nilsson G, Alitalo K, et al.: Endostatin overexpression inhibits lymphangiogenesis and lymph node metastasis in mice. Cancer Res 2007, 67:11528-11535.

5I. Isayeva T, Chanda D, Kallman L, Eltoum IE, Ponnazhagan S: Effects of sustained antiangiogenic therapy in multistage prostate cancer in TRAMP model. Cancer Res 2007, 67:5789-5797.

Publish with Bio Med Central and every scientist can read your work free of charge

"BioMed Central will be the most significant development for disseminating the results of biomedical research in our lifetime. "

Sir Paul Nurse, Cancer Research UK

Your research papers will be:

- available free of charge to the entire biomedical community

- peer reviewed and published immediately upon acceptance

- cited in PubMed and archived on PubMed Central

- yours - you keep the copyright

Submit your manuscript here:

http://www.biomedcentral.com/info/publishing_adv.asp 